\title{
Crossing the Blood-Brain-Barrier: A bifunctional liposome for BDNF gene delivery - A Pilot Study
}

\author{
Danielle M. Diniz ${ }^{a}$, Silvia Franze ${ }^{b}$, Judith R. Homberg ${ }^{a}$
}

aDepartment of Cognitive Neuroscience, Donders Centre for Medical Neuroscience, Radboud University Medical Center, Geert Grooteplein 21, 6525 EZ, Nijmegen, The Netherlands.

${ }^{b}$ Department of Pharmaceutical Sciences, University of Milan, Via G. Colombo 71, 20133 Milan, Italy

\begin{abstract}
To achieve their therapeutic effect on the brain, molecules need to pass the blood-brain-barrier (BBB). Many pharmacological treatments of neuropathologies encounter the BBB as a barrier, hindering their effective use. Pharmaceutical nanotechnology based on optimal physicochemical features and taking advantage of naturally occurring permeability mechanisms, nanocarriers such as liposomes offer an attractive alternative to allow drug delivery across the BBB. Liposomes are spherical bilayer lipid-based nanocapsules that can load hydrophilic molecules in their inner compartment and on their outer surface can be functionally modified by peptides, antibodies and polyethyleneglycol (PEG). When composed of cationic lipids, liposomes can serve as gene delivery devices, encapsulating and protecting genetic material from degradation and promoting nonviral cell transfection. In this study, we aimed to develop a liposomal formulation to encapsulate a plasmid harbouring brain-derived neurotrophic factor (BDNF) and infuse these liposomes via the peripheral bloodstream into the brain. To this end, liposomes were tagged with PEG, transferrin, and arginine and characterized regarding their physical properties, such as particle size, zeta-potential and polydispersity index (PDI). Moreover, we selected liposomes preparations for plasmid DNA (pDNA) encapsulation and checked for loading efficiency, in vitro cell uptake, and transfection. The preliminary results from this pilot study revealed that we were able to replicate the liposomes synthesis described in literature, achieving compatible size, charge, PDI, and loading efficiency. However, we could not properly determine whether the conjugation of the surface ligands transferrin and arginine to PEG worked and whether they were attached to the surface of the liposomes. Additionally, we were not able to see transfection in SH-SY5Y cells after 24 or 48 hours of incubation with the pDNA loaded liposomes. In conclusion, we synthesized liposomes encapsulation pBDNF, however, further research will be necessary to address the complete physicochemical characterization of the liposomes. Furthermore, preclinical studies will be helpful to verify transfection efficiency, cytotoxicity, and in the future, safe delivery of BDNF through the BBB.
\end{abstract}

Keywords: liposome, nanotechnology, BBB, gene delivery, BDNF

\section{Introduction}

The development of new treatments for curing neurological diseases has been slow due to the inability of large molecule pharmaceuticals, such as products of biotechnology, recombinant proteins or gene therapies, to cross the blood-brain barrier (BBB) (Pardridge, 2020). The central nervous system (CNS) presents a series of barriers to protect itself from invading pathogens, neurotoxic molecules, and circulating blood cells. These structures with diverse degrees of permeability include the blood-brain barrier, which is the most extensive and exclusive barrier (Saraiva et al., 2016). The blood-brain-barrier (BBB) is an anatomical and physiological barrier that is responsible for the tight regulation of the transportation of cells, molecules, and ions between the periphery and the brain. Because the selective molecular permeability of the BBB prevents most of the drugs from entering into the brain, the development of new treatments for brain diseases is complicated (Pardridge, 2012). The highly specialized endothelial cells layer has an intimate contact with brain cells, so that to reach those cells, substances such as drugs, have to present suitable lipophilicity, size, and capacity to evade active extrusion (Serlin et al., 2015). The occurrence of specific receptors on the surface of the BBB facilitates the transport of various essential molecules into the brain. Nanotechnology offers an exciting approach for improving the therapeutic management of CNS diseases. Liposomes, being functionally versatile, can be engineered for targeting these receptors, thus rendering 
bioRxiv preprint doi: https://doi.org/10.1101/2020.06.25.171264; this version posted June 26, 2020. The copyright holder for this preprint (which was not certified by peer review) is the author/funder. All rights reserved. No reuse allowed without permission.

\section{M. Diniz et al.}

them as promising carriers for drug and gene delivery (Sharma et al., 2012). A liposome is a kind of non-viral vector that can deliver molecules such as DNA, proteins, and drugs to the action sites, and it has been used to carry exogenous gene productions (Ganly et al., 2013). They have the great advantage of being made from a natural biodegradable lipid bilayer, which is similar to the animal cell membrane structure. Thus, considering that the morphologic appearance of liposomes resembles the natural cell membrane, they are an ideal drug-carrier system (Bozzuto, 2015).

Bangham and Horne were the pioneers in reporting the synthesis of liposomes, described by them as single or multiple concentrically organized lipid bilayers containing an inner aqueous compartment (Bangham and Horne, 1964) (Figure 1). Liposomes usually contain phospholipids as its basic constitution. This lipid molecule is made up of a hydrophilic head that interacts with aqueous solutions and two hydrophobic fatty acids chains that have an affinity with each other. In aqueous solution, due to these amphiphilic characteristics, a lipid bilayer is formed creating a lipophilic inner compartment that acts as a permeability barrier, both inward and outward (Bozzuto, 2015). Liposomes can serve as gene carriers, being then called lipoplexes. Lipoplexes have enormous potential to deliver plasmids into target cells; they contain cationic lipids that due to its positive charge, can complex with negatively charged DNA molecules. Theoretically, the electrostatic interaction promotes neutralization and enhances cell-membrane-DNA communication and transfection efficiency (Parker et al., 2003). However, the positive charges on the surface can lead to nonspecific interaction with plasma and other extracellular proteins, decreasing the transfection efficiency (Urtti et al., 2000). Thus, to increase transfection, neutral or helper lipids, such as dioleoylphosphatidylcholine (DOPE), are used allow endosomal escape and plasmid dissociation from liposomes before degradation in lysosomes. (Parker et al., 2003).

To specifically target brain delivery, liposomes can undergo surface modifications to increase transfection efficiency. For instance, adding polyethylene glycol (PEG), or PEGylating the liposome, increases transfection efficiency, reduces toxicity, and imparts "stealth" properties (Rip et al., 2014). A widely explored liposome surface modification for brain delivery relies on the use of ligands of receptors on the brain endothelium. The cellpenetrating peptides (CPPs) are short cationic or amphipathic peptides that have the ability to transport the associated molecular cargo (e.g., peptides, proteins, oligonucleotides, liposomes, nanoparticles, bacteriophages, etc.) inside the cells (Sharma et al., 2012). Arginine, a CPP, can enhance the cellular uptake and delivery across the BBB (Morris and Labhasetwar, 2015). Moreover, the use of transferrin (Tf) is a classic method for enhancing BBB crossing via receptor-mediated endocytosis (Chen et al., 2016; dos Santos Rodrigues et al., 2020; Sharma et al., 2013, 2012; Sonali et al., 2016). In a recent study, dos Santos Rodrigues et al. (2020) successfully designed a dualmodified liposome containing CPP and transferrin ligands that promoted efficient delivery of a plasmid DNA in vitro and, into the mice brain.

Taking into consideration the large treatment inefficacy burdening individuals suffering from neuropsychiatric diseases, such as is the case of depression (Fornaro et al., 2014), the use of nanotechnology can widen up the possibilities for novel treatments. One attractive candidate is the brain-derived neurotrophic factor (BDNF), which is widely expressed in the CNS, especially in the hippocampus (Lessmann et al., 2003; Leßmann and Brigadski, 2009), and plays an important role in the regulation of several biological processes, including neuronal survival, differentiation, growth and plasticity (Alsina et al., 2001; Benarroch, 2015; Edelmann et al., 2014; Poo, 2001). It has been shown that BDNF is decreased in depressive patients (Dwivedi et al., 2003) and that antidepressant treatment increases BDNF levels (Fernandes et al., 2015; Polyakova et al., 2015; Sen et al., 2008). Local lentivirus BDNF infusion in the hippocampus alleviated depression-like behaviors in a rat model of poststroke depression (Chen et al., 2015). Our studies in the SERT ${ }^{-1-}$ rat model, which presents both decreased BDNF levels in the HIP and depression- and anxiety-like behaviors (Calabrese et al., 2015; Guidotti et al., 2012; Molteni et al., 2010), showed that BDNF lentivirus infusion meliorated their anxiety levels in the novelty-induced locomotor activity. Moreover, BDNF overexpression in the hippocampus of the SERT ${ }^{-1}$ rats, increased sucrose preference and intake in the sucrose consumption test, showing effects in anhedonia (Diniz et al. unpublished data). Despite promising results, BDNF local infusion into the human brain to treat depression seems to be not feasible. Moreover, neurotrophins, including BDNF do not readily cross the BBB (Pardridge, 2015). Therefore, the development of a delivery system to increase BDNF in the brain following a less invasive administration route might provide the opportunity to explore the enormous therapeutic potential of BDNF.

The present study sought to assess the feasibility to design a cell penetrating peptide tethered bi-ligand liposome for brain delivery of BDNF plasmid (Kim et al., 2014; Sharma et al., 2013, 2012). In this pilot experiment liposomes without any tag (plain liposomes), liposomes tagged with transferrin (Tf-liposomes), tagged with 
bioRxiv preprint doi: https://doi.org/10.1101/2020.06.25.171264; this version posted June 26, 2020. The copyright holder for this preprint (which was not certified by peer review) is the author/funder. All rights reserved. No reuse allowed without permission.

arginine (PR-liposomes), and bifunctional liposomes (Tf-PR-liposomes) were developed and characterized for the main physical properties, such as particle size, zeta-potential, polydispersity index (PDI) was done (see schematic representation in figure 1). Moreover, selected liposomes preparations were used for pDNA encapsulation and checked for loading efficiency, in vitro cell uptake and transfection. Pilot synthesis and characterization of the liposomal delivery system aimed to assess in first instance the efficiency of BDNF plasmid encapsulation, pursuing to the further development of a non-viral system to mediate delivery across the BBB following peripheral blood stream infusion route. mRNA BDNF overexpression in the CNS is a promising approach to remediate the decreased BDNF protein levels encountered in neurological diseases such as mood disorders.

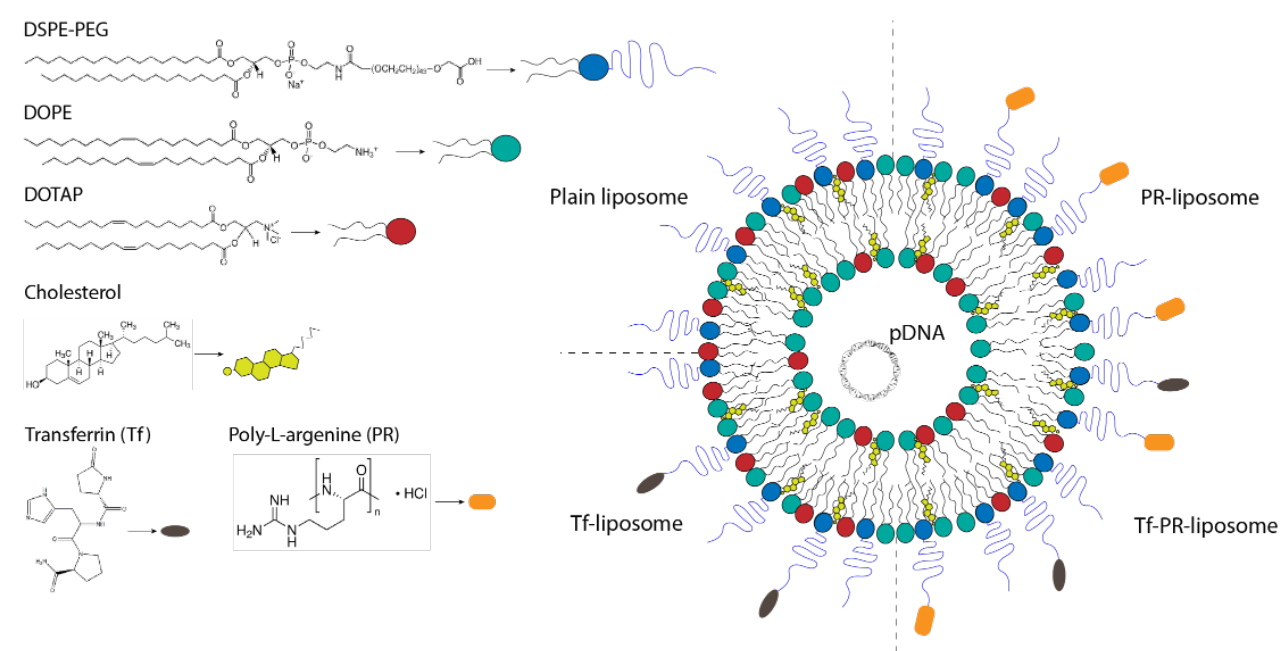

Figure 1. Schematic representation of the bifunctional liposomes. The structure of the lipids composing the liposome bilayer, the theoretical organization of the functional targeting with transferrin and/or arginine, and the encapsulation of the plasmid DNA (pDNA) are considered. According to Sharma et al. (2012), the following formulations were developed: Plain liposome (DOTAP/DOPE/DSPE-PEG/Cholesterol 45:45:8:2 mol \%), PR-liposome (DOTAP/DOPE/DSPE-PEG/PR-PEG /Cholesterol 45:45:4:4:2 mol \%), Tf-liposome (DOTAP/DOPE/DSPE-PEG/Tf-PEG /Cholesterol 45:45:4:4:2 mol \%), Tf-PR-liposomes (DOTAP/DOPE/PR-PEG/Tf-PEG /Cholesterol 45:45:4:4:2 mol \% ).

\section{Material and Methods}

\section{Materials}

1,2-distearoyl-sn-glycero-3-phosphoethanolamine-N-[carboxy(polyethylene glycol) 2000] (DSPE-PEG2000$\mathrm{COOH})$, 1,2-Dioleoyl-sn-glycero-3-phosphoethanolamine (DOPE), and 1,2 Dioleoyl-3-trimethylammoniumpropane chloride (DOTAP) were purchased from Avanti Polar Lipids (Alabaster, Alabama). Poly-L-arginine hydrochloride (molecular weight $=13,300 \mathrm{Da}$ ), holo-Transferrin human (Transferrin), 3ß-Hydroxy-5-cholestene (Cholesterol), N-(3-Dimethylaminopropyl)-N'-ethylcarbodiimide hydrochloride (EDC), and N-Hydroxysuccinimide (NHS) were procured from Sigma-Aldrich Company (Darmstadt, Germany). The fluorescent dye 1,1'-dioctadecyl3,3,3', $3^{\prime}$-tetramethyl-indocarbocyanine iodide (DiR) was obtained from Invitrogen (Landsmeer, Netherlands). BDNF (NM_012513) Rat Untagged plasmid was purchased from Origene (OriGene Technologies GmbH, Germany). All other chemicals used in this study were of analytical reagent grade.

\section{Methods:}

\section{Coupling poly-L-arginine (PR) to DSPE-PEG}

To obtain PR-liposomes, first, poly-L-arginine (PR) had to be coupled to DSPE-PEG. The synthesis procedure of PRPEG was based on the previously described method (Huang et al., 2002). Briefly, PR was dissolved in $25 \mathrm{ml}$ of $50 \mathrm{mM}$ sodium tetraborate buffer (STBB, $\mathrm{pH}$ 8.5) per gram of PR. The resulting solution was stirred vigorously for approximately $30 \mathrm{~min}$ and subsequently filtered through a $0.22 \mu \mathrm{m}$ Durapore ${ }^{\circledR}$ membrane (Sterile Millex GV, Sigma-Aldrich, Buchs, Switzerland) into a sterile culture tube. The appropriate stoichiometric amount of DSPE- 
bioRxiv preprint doi: https://doi.org/10.1101/2020.06.25.171264; this version posted June 26, 2020. The copyright holder for this preprint (which was not certified by peer review) is the author/funder. All rights reserved. No reuse allowed without permission.

\section{M. Diniz et al.}

PEG powder was then slowly added to the solution while it was continuously stirred. After another 6h of vigorous stirring at room temperature, the solution was transferred to a dialysis tube (Spectr/Por dialysis tubing, M.W.C.O. of 6-8 kDa, Spectrum Laboratories, Inc., Rancho Dominguez, CA). The synthesized product was dialyzed out for $24 \mathrm{~h}$ in $10 \mathrm{mM}$ phosphate-buffered saline (PBS, $\mathrm{pH} 7.0$ ), followed by an additional $24 \mathrm{~h}$ of dialysis in deionized water. The product was then freeze-dried for $48 \mathrm{~h}$ at $-70 \circ \mathrm{C}$ with a pressure of $0.2 \mathrm{mbar}$.

\section{Verification of PR-PEG coupling}

Coupling efficiency was analyzed through size-exclusion high-performance liquid chromatography performed using Agilent 1100 series HPLC system (Agilent Technologies Inc., California, USA). Two tandem Shodex Protein KW803 $(8.0 \mathrm{~mm} \times 300 \mathrm{~mm}, 5 \mu \mathrm{m})$ and $\mathrm{KW} 804(8.0 \mathrm{~mm} \times 300 \mathrm{~mm}, 7 \mu \mathrm{m})$ columns were used at ambient temperature. The mobile phase is an aqueous solution containing 20mMHEPES buffer at pH 6.5 (prepared by dissolving $4.42 \mathrm{~g}$ of HEPES and $0.38 \mathrm{~g}$ of HEPES sodium salt in $1000 \mathrm{~mL}$ of water and filtered through a $0.45 \mu \mathrm{m}$ filter before use), and the flow rate was $0.5 \mathrm{~mL} / \mathrm{min}$. Stock solutions of $1 \mathrm{mg} / \mathrm{mL}$ PR-PEG were injected. The HPLC trace was monitored with a UV/vis detector at a wavelength of $214 \mathrm{~nm}$ and with a RI detector at an attenuation of $7.8 \times 10^{3}$.

\section{Preparation of plain and PR-liposomes}

Liposomes were prepared by lipid film hydration method as previously reported (Kim et al., 2010; Sharma et al., 2012). In short, stock solutions of each lipid in an organic solvent mixture $\left(\mathrm{CHCl}_{3}: \mathrm{MeOH}=2: 1, \mathrm{v} / \mathrm{v}\right)$ were mixed in the following molar ratio: DOTAP/DOPE/DSPE-PEG/Cholesterol 45:45:8:2 and DOTAP/DOPE/DSPE-PEG/PRPEG/Cholesterol 45:45:4:4:2 mol/mol \% for plain and PR-liposomes, respectively. The organic mixture was removed on a rotary evaporator under reduced pressure with the temperature of water bath adjusted to $40 \circ \mathrm{C}$. Lipid film was hydrated with PBS buffer $(\mathrm{pH}$ 7.4) by vigorous vortexing. The resulting liposome dispersion was extruded 10 times (Avanti ${ }^{\circledR}$ Mini-Extruder, Avanti Polar Lipids, Inc.) using $0.2 \mu \mathrm{m}$ polycarbonate membranes.

\section{Development of Tf-PR liposomes}

Bifunctional liposomes were prepared using the post-insertion technique (Sharma et al., 2012; Visser et al., 2005). Transferrin (Tf) was coupled to the phospholipid DSPE-PEG-COOH as reported previously (Li et al., 2009). Briefly, DSPE-PEG-COOH (remaining $4 \mathrm{~mol} \%$ of the total phospholipid content) was suspended in HEPES-buffered saline ( $\mathrm{pH}$ 5.0) to form micelles. The micellar suspension was then treated with $360 \mu \mathrm{L}$ of both EDC $\left(0.5 \mathrm{M}\right.$ in $\left.\mathrm{H}_{2} \mathrm{O}\right)$ and NHS $\left(0.5 \mathrm{M}\right.$ in $\left.\mathrm{H}_{2} \mathrm{O}\right)$ per $10 \mu \mathrm{mol}$ of the phospholipid. Excess EDC was removed by dialysis, and the $\mathrm{pH}$ of the micellar suspension was adjusted to 7.3 with $0.1 \mathrm{~N}$ sodium hydroxide. Tf ( $125 \mu \mathrm{g} / \mu \mathrm{mol}$ of the lipid) was added to the resulting suspension and stirred at $25^{\circ} \mathrm{C}$ for about $8 \mathrm{~h}$. The resulting Tf micelles were stirred overnight with PR liposomes at room temperature, and the final liposomal dispersion was passed through a Sepharose ${ }^{\circledR} \mathrm{CL}-4 \mathrm{~B}$ column to remove unbound protein.

\section{Protein assay and Tf-binding efficacy}

The average amount of transferrin conjugated to the liposome was quantified as described by (Anabousi et al., 2005). Shortly, one hundred microlitres of liposome dispersion were added to $400 \mu \mathrm{l}$ of methanol. The mixture was vortexed and centrifuged (10s at $9000 \times$ g). Then, $200 \mu \mathrm{l}$ of chloroform were added, followed by vortexing and centrifugation (10s at $9000 \mathrm{x}$ ). For phase separation, $300 \mu \mathrm{l}$ of water were added, and the sample was vortexed again and centrifuged for $1 \mathrm{~min}$ at $9000 \mathrm{xg}$. The upper phase was carefully removed and discarded. Three hundred microliters of methanol were added to the chloroform phase and the interphase with the precipitated protein. The sample was mixed and centrifuged to pellet the protein $(2 \mathrm{~min}$ at $9000 \times \mathrm{g}$ ). Then, the supernatant was removed, and the protein pellet was dried under a stream of air. The pellet was then dissolved in $20 \mu \mathrm{l}$ of PBS (pH 7.4), and the concentration was determined with a bicinchoninic acid (BCA) protein assay using pure holotransferrin as standard. The coupling efficiency was calculated as $\mathrm{mg} \mathrm{Tf} / \mathrm{mmol} \mathrm{PL}$. 
bioRxiv preprint doi: https://doi.org/10.1101/2020.06.25.171264; this version posted June 26, 2020. The copyright holder for this preprint (which was not certified by peer review) is the author/funder. All rights reserved. No reuse allowed without permission.

\section{BDNF plasmid transformation and purification}

In order to have enough pBDNF for the liposomal formulations, the pBDNF amount was increased through bacterial transformation into E. coli (DH10ß), which was performed using the heat shock method (Froger and Hall, 2007). In short, after a 10 minutes incubation in ice, the mixture of bacteria and pDNA was placed at $42^{\circ} \mathrm{C}$ for 90 seconds (heat shock) and then placed back in ice. LB media was added, and the transformed cells were incubated at $37^{\circ} \mathrm{C}$ for 45-60 min with agitation. To check that isolating colonies are irrespective of transformation efficiency, two quantities of transformed bacteria were plated. The number of pBDNF copies were quantified by $\mathrm{OD}_{600}$ using an UV-visible spectrophotometer (NanoDrop ${ }^{\mathrm{TM}}$, USA).

After achieving the desired amplification, pBDNF was purified using the endotoxin-free plasmid purification NucleoBond ${ }^{\circledR}$ Xtra system (Macherey-Nagel, Germany). The final concentration was measured by $\mathrm{OD}_{260}$ using an UV-visible spectrophotometer (NanoDrop ${ }^{\mathrm{TM}}$, USA), and diagnostic restriction digestion was used to confirm the rough structure of the plasmid on agarose gel electrophoresis $1 \%$ TEB buffer.

\section{pDNA encapsulation}

Plasmid DNA was incorporated at N/P ratio of 5 into the formulation using the encapsulation method or the complexation method as previously described (Sharma et al., 2012). Shortly, in the encapsulation method, plasmid DNA was added to the hydration buffer, which was added to the lipid film and vigorously vortexed at room temperature for about 20 minutes, followed by extrusion and size exclusion column (SEC) purification (Sharma et al., 2012). In the complexation method, pDNA was added after liposomes were extruded, gently mixed and incubated for about 30 minutes to allow the lipoplex formation. Thereafter complexed liposomes were purified through SEC (Kim et al., 2010).

\section{Characterization of liposomes: \\ Particle size and zeta potential measurements}

Dynamic light scattering (DLS) is a technique in physics that can be used to determine the size distribution profile of small particles in suspension or polymers in solution (Pecora, 2000). DLS measures the time-dependent fluctuations in the intensity of scattered light, which occurs because particles (liposomes) in a suspension undergo random Brownian motion due to collisions between suspended particles and solvent molecules (Bozzuto, 2015). Therefore, the DLS allowed us to analyze the particle size and polydispersity index (PDI).

The $\zeta$-potential is the overall charge of a particle acquires in a particular medium. A Laser Doppler Microelectrophoresis was used to measure zeta potential. An electric field is applied to a solution of molecules or a dispersion of particles, which then move with a velocity related to their zeta potential. This velocity is measured using a patented laser interferometric technique called M3-PALS (Phase analysis Light Scattering), enabling the calculation of electrophoretic mobility, and from this, the zeta potential and zeta-potential distribution.

The size distribution, the average hydrodynamic particle size, and the zeta potential of the liposomes were evaluated using both systems described above, which are incorporated in the Zetasizer Nano (Malvern Instruments, UK). The samples were diluted in PBS-buffered saline (pH 7.4), and transferred into a disposable cuvette for particle size analysis and a capillary cell for $\zeta$-potential measurement and inserted into the Zetasizer (Nano-ZS, Malvern Instrument, UK) at $25^{\circ} \mathrm{C}$.

\section{Measurement of plasmid BDNF Encapsulation Efficiency}

The pBDNF encapsulation efficiency of the liposomes was calculated based on the previously reported method (Fillion et al., 2001; Gonçalves et al., 2004). DNA content of the samples was analyzed through a spectrophotometer. Shortly, DNA concentration was estimated by measuring the absorbance at 260nm, adjusting the $A_{260}$ measurement for turbidity (measured by absorbance at $320 \mathrm{~nm}$ ), multiplying by the dilution factor, and using the relationship that an $\mathrm{A}_{260}$ of $10=50 \mu \mathrm{g} / \mathrm{mL}$ pure dsDNA.

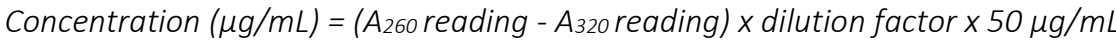


bioRxiv preprint doi: https://doi.org/10.1101/2020.06.25.171264; this version posted June 26, 2020. The copyright holder for this preprint (which was not certified by peer review) is the author/funder. All rights reserved. No reuse allowed without permission.

\section{M. Diniz et al.}

\section{Cell cultures}

SH-SY5Y cells were cultured in Dulbecco's modified Eagle's Medium (DMEM, Life Technologies), with 7.5\% Fetal calf serum (FCS), $400 \mathrm{U} / \mathrm{ml}$ penicillin and $100 \mu \mathrm{g} / \mathrm{ml}$ streptomycin (Gibco), at $37^{\circ} \mathrm{C}$ in a $5 \% \mathrm{CO}_{2}$ incubator. The cells were passed once a week, in a 1:5 dilution.

\section{Evaluation of In-vitro Transfection Efficiency}

Cells were cultured for 24 hours in a 12 wells plate, $10^{3}$ cells/well. After these 24 hours, 1000nM of liposomes containing GFP plasmid was added. The medium was refreshed after 1 hour. The cells were kept in an Evos FL Auto 2 cell imaging system (Invitrogen). Hourly images were automatically captured to visualize the GFP expression. The cells were kept inside the Evos at $37^{\circ} \mathrm{C}$ in $5 \% \mathrm{CO}_{2}$.

\section{Results and discussion \\ Resolving free DSPE-PEG from PEG-PR conjugate}

The synthesis of the conjugate PEG-PR was particularly challenging. Because of the anticipated difficulty in revolving free PEG and PEG-conjugate, our initial efforts were focused on the identification of conditions separating these two species. We had to use different kinds of dialysis membranes to purify not only from free PEG, but also from free poly-L-arginine. During the freeze-drying procedure, we observed that the PEG-PR sample did not present loss of weight, indicating that the water molecules were not removed from the sample, and resulting in precipitation/ flocculation when we attempted to dilute PEG-PR in an organic solvent for the liposome preparation. According to Radaev and Sun (2002), during freezing, PEG tends to crystallize. This could explain increased water retention by the system (Tattini et al., 2005), and therefore solubility problems. Following the protocol proposed by Kim et al. (2010), we freeze-dried the PEG-PR solution for $48 \mathrm{~h}$ at $-70 \circ \mathrm{C}$ with a pressure of 0.2 mbar. We also tried to decrease the temperature to $-86^{\circ} \mathrm{C}$ and the pressure to $0.006 \mathrm{mbar}$; however, we encountered the same solubility problem.

Moreover, when measuring PEG-PR coupling efficiency through HPLC, we injected samples of $1 \mathrm{mg} / \mathrm{mL}$ solutions of PR, PEG, and PEG-PR. We were not able to see a clear peak of the PR, PEG, or the PR-PEG conjugate. Altogether, we conclude that further studies are necessary to characterize the PEG-PR conjugation better. For example, through differential scanning calorimetry (DSC), the effects of the freeze-drying method over the structural and phasic changes in the conjugation of PEG with PR can be determined (Tattini et al., 2005). Additionally, Kim et al. (2010) confirmed the synthesis of PEG-PR through ${ }^{1} \mathrm{H} N M R$ in $\mathrm{D}_{2} \mathrm{O}$ and gel permeation chromatography (GPC). Therefore, we will have to repeat the experiments and perhaps the use of other techniques could help in the identification of the coupling efficiency of the PEG-PR. The samples produced that achieved organic solvent solubility were used to develop the liposome formulations.

\section{Tf-binding efficacy}

We planned to access the amounts of transferrin using a bicinchoninic acid (BCA) assay following Anabousi et al. (2005). We did not conduct the entire experiment, but following the specifications of the manufacturer (BCA ${ }^{\mathrm{TM}}$, Scientific, USA), we built a calibration curve using human transferrin, which would be used as the standard to analyze the transferrin content in the liposomes. The BCA assay offers the advantage of producing a linear response curve. This response curve allows accurate determination of unknown protein concentrations in the liposome surface. Given that the PEG-Tf micelles contained transferrin concentration of about $58 \mu \mathrm{g} / \mathrm{mL}$, which are post-inserted to the already formed and extruded liposomes, and giving the possibility that not all chains of PEG are incorporated to the final Tf-liposome, we built the curve with concentrations starting from $5 \mu \mathrm{g} / \mathrm{mL}$. The linear response curve $\left(R^{2}>0.95\right)$ obtained is showed in figure 2 and it will help us to further determine the amount of transferrin in the liposomes. 


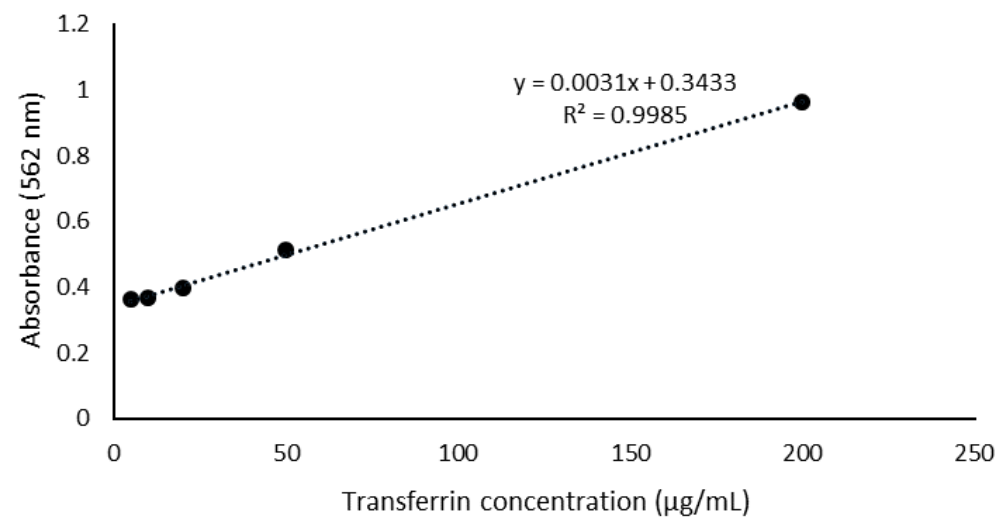

Figure 2. Standard curve for transferrin quantitation. Holo transferrin human in $0.9 \%$ saline $(5-200 \mu \mathrm{g} / \mathrm{mL}$ ) was used to generate standard curves for the BCA Protein Assay. The assay was conducted according to the manufacturer's protocols in a test-tube format.

\section{pBDNF purification}

Plasmid BDNF purification was checked by UV spectroscopy using the ratio of $A_{260} / A_{280}$ and $A_{260} / A_{230}$. We verified a ratio of $A_{260} / A_{280}=1.84 \pm 0.01$ and $A_{260} / A_{230}=2.3$, indicating that the obtained samples contained a pure plasmid DNA (NucleoBond ${ }^{\circledR}$ Xtra, Macherey-Nagel, Germany). Figure 3 demonstrates the result of the diagnostic restriction digestion. According to the manufacturer, the pCMV6-Entry plasmid backbone plus the BDNF insert (NM_012513) has about $5.6 \mathrm{~kb}$ (OriGene Technologies $\mathrm{GmbH}$, Germany). We notice that digestion with the restriction enzyme Hind III should have linearized both the supercoiled and nicked forms of the plasmid, but there has probably been an incomplete digestion. Therefore, although spectroscopy analysis indicates that we obtained copies of the pBDNF, to check the size and the characteristics of the plasmid correctly, we will probably need to increase the enzyme and/or increase the incubation time to ensure complete digestion.

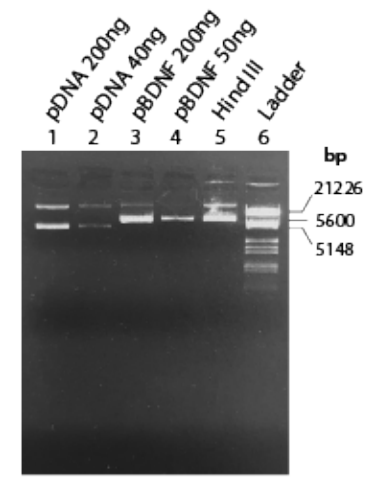

Figure 3. Evaluation of the pBDNF amplification and purification in agarose gel 1\% TEB. Standard plasmids of known concentration were used (lanes 1 and 2), and two different concentrations were used to check uncut pBNDF (lanes 3 and 4). Digestion of 250ng of pBDNF by Hind III is expressed in lane 5, and marker III (Roche) was used as DNA molecular weight marker.

\section{Particle size, zeta potential and PDI characterization of the liposomes}

Determining the physicochemical properties of the liposomes is essential because it can assess its passage mechanism across the BBB (Saraiva et al., 2016). There is evidence for a inverse correlation between BBB penetration and the size of the liposome (Etame et al., 2011; Hanada et al., 2014; Sonavane et al., 2008). The preferred size for brain delivery is $100 \mathrm{~nm}$ or smaller, but studies have shown that liposomes from 100 to $140 \mathrm{~nm}$ have certain advantages, such as a longer half-life in blood circulation and avoidance of plasma proteins (Ross et al., 2018). Moreover, because the BBB is negatively charged, cationic liposomes can trigger cell internalization through electrostatic interactions (Harilal et al., 2020). The physico-chemical characterization of the main properties of prepared liposomes are reported in table 1. 
bioRxiv preprint doi: https://doi.org/10.1101/2020.06.25.171264; this version posted June 26, 2020. The copyright holder for this preprint (which was not certified by peer review) is the author/funder. All rights reserved. No reuse allowed without permission.

D. M. Diniz et al.

Table 1. Particle Size, polydispersity index (PDI), and zeta (ろ)-potential of liposomes before and after coupling of transferrin (Tf) and poly-L-arginine (PR) at pH 7.4. Data are shown as means and standard deviation $(n=3)$. nd: not determined.

\begin{tabular}{llll}
\hline & \multicolumn{3}{c}{ Physical properties } \\
\cline { 2 - 4 } Liposome composition & Particle Size $(\mathrm{nm})$ & PDI & $\zeta$-potential $(\mathrm{mV})$ \\
\hline Plain (empty) & $157.6 \pm 1.1$ & $0.102 \pm 0.013$ & $7.16 \pm 0.72$ \\
Plain (encapsulating pBDNF) & $138.9 \pm 0.8$ & $0.1065 \pm 0.013$ & $5.915 \pm 0.71$ \\
Plain (complexated with pBDNF) & $178.4 \pm 0.8$ & $0.082 \pm 0.033$ & $-4.18 \pm 2.94$ \\
Tf-liposomes (encapsulating pBDNF) & $125.1 \pm 0.6$ & $0.152 \pm 0.014$ & $-8.73 \pm 1.13$ \\
PR-liposomes (encapsulating pBDNF) & $124.7 \pm 0.5$ & $0.106 \pm 0.014$ & $7.83 \pm 0.68$ \\
Tf-PR-liposomes (empty) & $177.24 \pm 75.5$ & nd & nd \\
\hline
\end{tabular}

As expressed in table 1, the different liposome preparations present diverse physical properties. As expected, the results showed that the incorporation of Tf decreased the zeta potential to a negative value. Anabousi et al. (2005) have demonstrated that using DSPE-PEG $2000-\mathrm{COOH}$ as linker lipid led to the highest amount of bound Tf, and the negative charge of the $\zeta$-potential indicated that Tf was attached to the liposome surface. On the other hand, usually, the coupling of PR to the liposome surface yields a higher positive charge. Sharma et al. (2012) demonstrated that PR-liposomes presented a క-potential of $20.25 \pm 3.6 \mathrm{mV}$, which were stable after 30 days storage presenting $\zeta$-potential of $21.30 \pm 3.5 \mathrm{mV}$ (Sharma et al., 2013). Kim et al. (2010) have also shown that

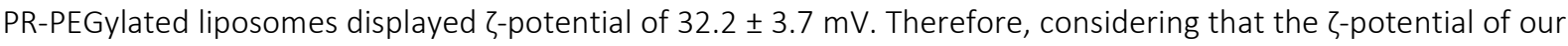
PR-liposomes was very similar to that of the plain liposomes, we can suggest that PR-PEG coupling efficiency was either low or did not occur.

Furthermore, we also noticed that the different ways of loading the liposomes with pDNA generated different phisical characteristics in the plain liposomes. The addition of pDNA during liposome formation resulted in posively charged liposomes (Parker et al., 2003). Lipoplexes formulations, in which pDNA was added to the solution containing the already formed liposome (Kim et al., 2010), instead showed a slight negative $\zeta$-potential, suggesting the presence of a higher amount of pDNA on the surface of liposomes. Sakurai et al., (2000) showed that cationic liposomes can aquire a negative charge depending on the amount of plasmid added to the formulation. Thus, it is likely that the pDNA post-added to the liposome formulation modulated the $\zeta$-potential conferring negative surface charge to the plain liposomes.

\section{Plasmid encapsulation efficiency}

The pDNA loading efficiencies for plain, Tf, and PR-liposomes were 44.1\%, 27.6\%, and 57.5\%, respectively. Our results are in agreement with those of Sharma et al. (2012), in which plain liposomes presented an efficiency loading of $35 \pm 4.3 \%$, and Tf- and PR-liposomes, encapsulation efficiencies of $33 \pm 5.2 \%$ and $40 \pm 4.1 \%$. However, we observed that several factors interfered with the absorbance measurements. For example, we initially used $1 \%$ Triton-x in order to break the liposomes and measure the freed pDNA concentration. However, we observed that the Triton-x interfered with the DNA measurement showing absorbance at $260 \mathrm{~nm}$. We replace the Triton-x by methanol (Podesta and Kostarelos, 2009; Zhang et al., 2010), and then, we were able to achieve more reliable results. Still, for further studies, we would like to conduct agarose gel electrophoresis to better access the pDNA content of the liposomes (Kim et al., 2010).

\section{Gene expression}

Plain liposomes and PR-liposomes encapsulating pGFP were used to access the transfection efficiency in neuroblastoma cells (SH-SY5Y) using a live-observing fluorescent microscopy. Figure 4 shows the bright field representation of the images taken during the experiment. We were not able to observe any fluorescence emission 0, 24, 48 or even 72 hours after adding the liposomes to the cells, indicating that these liposomes did not transfect the cells. The neuroblastoma cells line used in this study are often used to understand neuronal 
bioRxiv preprint doi: https://doi.org/10.1101/2020.06.25.171264; this version posted June 26, 2020. The copyright holder for this preprint (which was not certified by peer review) is the author/funder. All rights reserved. No reuse allowed without permission.

signaling. These cells are typically transfected via the calcium phosphate method or electroporation (Carrì et al., 1997; Hasegawa et al., 2004), but also different reports demonstrated successful transfection with liposomes, indicating that these cells should be sensitive to liposomal transfection (Betz et al., 2003; Obata et al., 2010). Therefore, other factors might have contributed to the failure of the transfection. It is likely, for example, that the cells did not uptake the liposomes or that the purification of the liposomes was not sufficient leading to cytotoxic effect over the cells. In conclusion, further improvement of the liposome synthesis will be necessary to achieve optimal transfection.
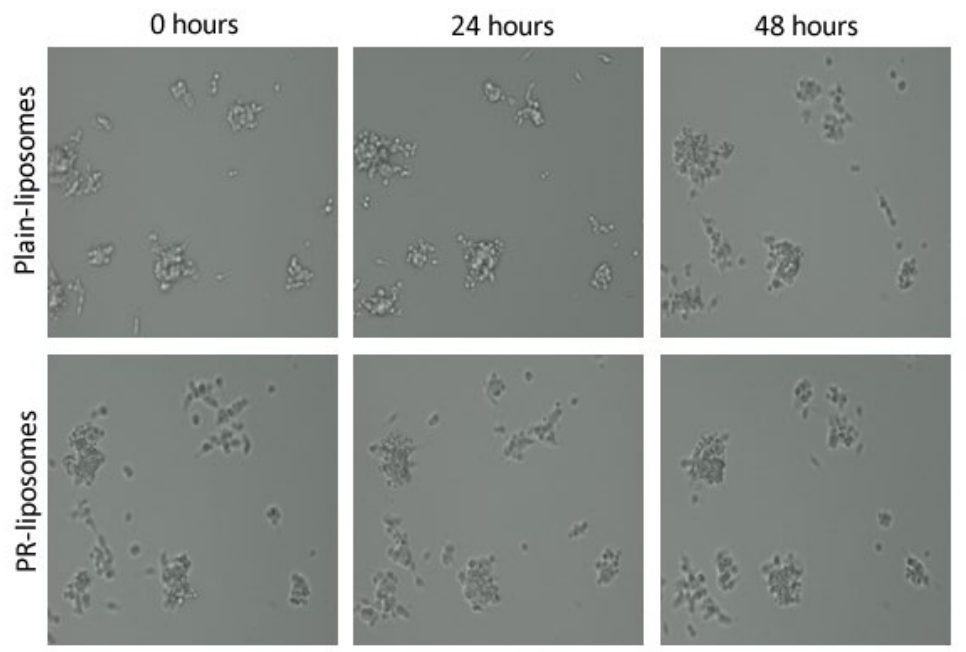

Figure 4. Live-cell imaging of SH-SY5Y cells transfected by plain and PR-liposomes using Invitrogen EVOS M7000 Imaging System. Bright-field and fluorescence pictures were taken hourly by the automated microscope. Selected bright-field images at 0,24 , and 48 hours were chosen to represent the study, but fluorescence images did not display any emission.

\section{Conclusion and perspectives}

In this study, we described the preparation of liposomal carriers to promote gene delivery through the bloodbrain-barrier. We synthesized plain liposomes containing cationic lipids and PEGylated surface, PR-liposomes containing the cell-penetrating peptide arginine, and Tf-liposomes containing transferrin which promotes receptor-mediated endocytosis. Moreover, we used both conjugates to develop the bifunctional dual-targeted TfPR-liposomes. This pilot study revealed the challenges of tagging the liposomes with the ligands Tf and PR. Notably, we encountered several limitations when verifying the coupling efficiency between the DSPE-PEG and the conjugates PR and Tf. Purification of the free peptides from the final liposomal product is a critical step to effectively validate liposome formulations for their clinical use to ensure that the observed therapeutic effects are due to the liposome conjugate and not from non-conjugated contaminants (Manjappa et al., 2011; Nobs et al., 2004). This step in the liposome production will therefore need further analysis.

Once the pBDNF-loaded liposome carrier is well characterized, subsequent studies should evaluate the delivery of specific BDNF gene transcripts to target desired brain regions (Aid et al., 2007; Baj et al., 2011; Pruunsild et al., 2007). Besides vector modifications, gene delivery efficiency can also be dramatically enhanced through strategic modification of DNA composition and conformation, thereby improving bioavailability, biocompatibility, durability, and safety (Foldvari et al., 2016). The use of cell-type-specific promoters will confine the transgene expression to a specific cell type. For example, decreased BDNF levels in the hippocampus characterize the pathology of depression (Castrén et al., 2007; Castrén and Rantamäki, 2010; Dwivedi et al., 2003; Ray et al., 2011). Identification of the subcellular localization of the hippocampal BDNF decrease will help in the desing of a plasmid vector that contains a promoter enhancing BDNF gene expression in that specific cellular subpopulation. In principle, specifically targeting a population of neurons or glial cells might allow to achieve the therapeutic goal 
bioRxiv preprint doi: https://doi.org/10.1101/2020.06.25.171264; this version posted June 26, 2020. The copyright holder for this preprint (which was not certified by peer review) is the author/funder. All rights reserved. No reuse allowed without permission.

\section{M. Diniz et al.}

without off-target effects (Ingusci et al., 2019). For example, the phosphate-activated glutaminase (PAG) or the vesicular glutamate transporter (vGLUT) promoter ensures $~ 90 \%$ glutamatergic neuron-specific expression, whereas the glutamic acid decarboxylase (GAD) promoter ensures $\sim 90 \%$ GABAergic neuron-specific expression (Rasmussen et al. (2007). Furthermore, the specific cellular location of the astrocyte-specific glial fibrillary acidic protein (GFAP) in the CNS has encouraged its extensive use to target transgene expression to cells of glial origin (Lee et al., 2008). Astrocytes as a target is desirable because this cell is in immediate contact with the BBB; additionally, a study designed by Quesseveur et al. (2013) indicated that BDNF released from astrocytes acts on post-synaptic cells in the hippocampus to stimulate neurogenesis, and mediate related anxiolytic-and antidepressant-like activities.

Combining several physico-chemical and genetic modifications into multicomponent non-viral vectors, such as liposomes, is an ongoing challenge but should prove possible. Optimizing both vector and genetic load provides a powerful tactic for development of effective non-viral gene therapy systems that might lead to a new therapeutic approach to deliver BDNF to the brain. Although further research is necessary to determine the safety of gene therapy and to improve drug targeting, liposome-mediated gene transfer is a promising avenue of research into the treatment of central nervous system diseases.

\section{Acknowledgement}

We would like to thank professor Paola Minghetti (department of Pharmaceutical Sciences from the University of Milan) and professor Gerard Martens (department of Molecular Animal Physiology, Radboud University Medical Center) for providing the expertise and facilities for the experiments described in this study. We would like to also thank Dr. Joanes Grandjean for helpful discussions, suggestions, and critical reading of the manuscript.

\section{Funding}

This work was supported by the Science Without Borders scholarship program from CNPq - Conselho Nacional de Desenvolvimento Científico e Tecnológico, of the Ministry of Science, Technology and Innovation of Brazil, grant \#200355/2015-5, awarded to DMD.

\section{References}

1. Aid, T., Kazantseva, A., Piirsoo, M., Palm, K., Timmusk, T., 2007. Mouse and ratBDNF gene structure and expression revisited. J. Neurosci. Res. 85, 525535. https://doi.org/10.1002/jnr.21139

2. Alsina, B., Vu, T., Cohen-cory, S., 2001. Visualizing synapse formation in arborizing optic axons in vivo : dynamics and modulation by BDNF $1093-1101$. https://doi.org/10.1038/nn735

3. Anabousi, S., Laue, M., Lehr, C.M., Bakowsky, U., Ehrhardt, C., 2005. Assessing transferrin modification of liposomes by atomic force microscopy and transmission electron microscopy. Eur. J. Pharm. Biopharm. 60, 295-303. https://doi.org/10.1016/j.ejpb.2004.12.009

4. Baj, G., Leone, E., Chao, M. V., Tongiorgi, E., 2011. Spatial segregation of BDNF transcripts enables BDNF to differentially shape distinct dendritic compartments. Proc. Natl. Acad. Sci. 108, 16813-16818. https://doi.org/10.1073/pnas.1014168108

5. Bangham, A.D., Horne, R.W., 1964. Negative staining of phospholipids and their structural modification by surface-active agents as observed in the electron microscope. J. Mol. Biol. https://doi.org/10.1016/S0022-2836(64)80115-7

6. Benarroch, E.E., 2015. Brain-derived neurotrophic factor: Regulation, effects, and potential clinical relevance. Neurology 84, $1693-1704$. https://doi.org/10.1212/wnl.0000000000001507

7. Betz, N., Farfan, A., Corporation, P., 2003. Transfecting a human neuroblastoma cell line with Monster GreenTM fluorescent protein. Cell Notes 7, 1416.

8. Bozzuto, G., 2015. Liposomes as Nanomedical Devices.pdf.crdownload 975-999.

9. Calabrese, F., van der Doelen, R.H.A., Guidotti, G., Racagni, G., Kozicz, T., Homberg, J.R., Riva, M.A., 2015. Exposure to early life stress regulates Bdnf expression in SERT mutant rats in an anatomically selective fashion. J. Neurochem. 132, 146-154. https://doi.org/10.1111/jnc.12846

10. Carrì, M.T., Ferri, A., Battistoni, A., Famhy, L., Gabbianelli, R., Poccia, F., Rotilio, G., 1997. Expression of a Cu,Zn superoxide dismutase typical of familial amyotrophic lateral sclerosis induces mitochondrial alteration and increase of cytosolic Ca2+ concentration in transfected neuroblastoma SH-SY5Y cells. FEBS Lett. https://doi.org/10.1016/S0014-5793(97)01051-X

11. Castrén, E., Rantamäki, T., 2010. The role of BDNF and its receptors in depression and antidepressant drug action: Reactivation of developmental plasticity. Dev. Neurobiol. 70, 289-297. https://doi.org/10.1002/dneu.20758

12. Castrén, E., Võikar, V., Rantamäki, T., 2007. Role of neurotrophic factors in depression. Curr. Opin. Pharmacol. https://doi.org/10.1016/j.coph.2006.08.009

13. Chen, H.H., Zhang, N., Li, W.Y., Fang, M.R., Zhang, H., Fang, Y.S., Ding, M.X., Fu, X.Y., 2015. Overexpression of brain-derived neurotrophic factor in the hippocampus protects against post-stroke depression. Neural Regen. Res. 10, 1427-1432. https://doi.org/10.4103/1673-5374.165510

14. Chen, Z.L., Huang, M., Wang, X.R., Fu, J., Han, M., Shen, Y.Q., Xia, Z., Gao, J.Q., 2016. Transferrin-modified liposome promotes $\alpha$-mangostin to penetrate the blood-brain barrier. Nanomedicine Nanotechnology, Biol. Med. https://doi.org/10.1016/j.nano.2015.10.021

15. dos Santos Rodrigues, B., Kanekiyo, T., Singh, J., 2020. In Vitro and In Vivo characterization of CPP and transferrin modified liposomes encapsulating pDNA. Nanomedicine Nanotechnology, Biol. Med. 102225. https://doi.org/https://doi.org/10.1016/j.nano.2020.102225 
16. Dwivedi, Y., Rizavi, H.S., Conley, R.R., Roberts, R.C., Tamminga, C.A., Pandey, G.N., 2003. Altered Gene Expression of Brain-Derived Neurotrophic Factor and Receptor Tyrosine Kinase B in Postmortem Brain of Suicide Subjects. Arch. Gen. Psychiatry 60, 804. https://doi.org/10.1001/archpsyc.60.8.804

17. Edelmann, E., Leßmann, V., Brigadski, T., 2014. Pre- and postsynaptic twists in BDNF secretion and action in synaptic plasticity. Neuropharmacology 76, 610-627. https://doi.org/10.1016/j.neuropharm.2013.05.043

18. Etame, A.B., Smith, C.A., Chan, W.C.W., Rutka, J.T., 2011. Design and potential application of PEGylated gold nanoparticles with size-dependent permeation through brain microvasculature. Nanomedicine Nanotechnology, Biol. Med. https://doi.org/10.1016/j.nano.2011.04.004

19. Fernandes, B.S., Molendijk, M.L., Köhler, C.A., Soares, J.C., Leite, C.M.G.S., Machado-Vieira, R., Ribeiro, T.L., Silva, J.C., Sales, P.M.G., Quevedo, J., Oertel-Knöchel, V., Vieta, E., González-Pinto, A., Berk, M., Carvalho, A.F., 2015. Peripheral brain-derived neurotrophic factor (BDNF) as a biomarker in bipolar disorder: A meta-analysis of 52 studies. BMC Med. https://doi.org/10.1186/s12916-015-0529-7

20. Fillion, P., Desjardins, A., Sayasith, K., Lagacé, J., 2001. Encapsulation of DNA in negatively charged liposomes and inhibition of bacterial gene expression with fluid liposome-encapsulated antisense oligonucleotides. Biochim. Biophys. Acta - Biomembr. 1515, 44-54. https://doi.org/10.1016/S00052736(01)00392-3

21. Foldvari, M., Chen, D.W., Nafissi, N., Calderon, D., Narsineni, L., Rafiee, A., 2016. Non-viral gene therapy: Gains and challenges of non-invasive administration methods. J. Control. Release. https://doi.org/10.1016/j.jconrel.2015.12.012

22. Fornaro, M., Martino, M., Mattei, C., Prestia, D., Vinciguerra, V., De Berardis, D., De Pasquale, C., lasevoli, F., Mungo, S., Fornaro, P., 2014. Duloxetinebupropion combination for treatment-resistant atypical depression: A double-blind, randomized, placebo-controlled trial. Eur. Neuropsychopharmacol. https://doi.org/10.1016/j.euroneuro.2014.04.004

23. Froger, A., Hall, J.E., 2007. Transformation of Plasmid DNA into E. Coli using the heat shock method. J. Vis. Exp. https://doi.org/10.3791/253

24. Ganly, S., Hynes, S.O., Sharif, F., Aied, A., Barron, V., McCullagh, K., McMahon, J., McHugh, P., Crowley, J., Wang, W., O’Brien, T., Greiser, U., 2013. Liposomal surface coatings of metal stents for efficient non-viral gene delivery to the injured vasculature. J. Control. Release. https://doi.org/10.1016/j.jconrel.2013.01.036

25. Gonçalves, E., Debs, R.J., Heath, T.D., 2004. The Effect of Liposome Size on the Final Lipid/DNA Ratio of Cationic Lipoplexes. Biophys. J. 86, 1554-1563. https://doi.org/10.1016/S0006-3495(04)74223-X

26. Guidotti, G., Calabrese, F., Auletta, F., Olivier, J., Racagni, G., Homberg, J., Riva, M.A., 2012. Developmental influence of the serotonin transporter on the expression of Npas4 and GABAergic markers: Modulation by antidepressant treatment. Neuropsychopharmacology 37, 746-758. https://doi.org/10.1038/npp.2011.252

27. Hanada, S., Fujioka, K., Inoue, Y., Kanaya, F., Manome, Y., Yamamoto, K., 2014. Cell-based in vitro blood-brain barrier model can rapidly evaluate nanoparticles' brain permeability in association with particle size and surface modification. Int. J. Mol. Sci. https://doi.org/10.3390/ijms15021812

28. Harilal, S., Jose, J., Parambi, D.J.G., Kumar, R., Unnikrishnan, M.K., Uddin, M.S., Mathew, G.E., Pratap, R., Marathakam, A., Mathew, B., 2020. Revisiting the Blood-brain barrier: A hard nut to crack in the transportation of drug Molecules. Brain Res. Bull. https://doi.org/10.1016/j.brainresbull.2020.03.018

29. Hasegawa, T., Matsuzaki, M., Takeda, A., Kikuchi, A., Akita, H., Perry, G., Smith, M.A., Itoyama, Y., 2004. Accelerated $\alpha$-synuclein aggregation after differentiation of SH-SY5Y neuroblastoma cells. Brain Res. https://doi.org/10.1016/j.brainres.2004.04.018

30. Ingusci, S., Verlengia, G., Soukupova, M., Zucchini, S., Simonato, M., 2019. Gene Therapy Tools for Brain Diseases. Front. Pharmacol. https://doi.org/10.3389/fphar.2019.00724

31. Kim, B.K., Seu, Y.B., Bae, Y.U., Kwak, T.W., Kang, H., Moon, I.J., Hwang, G.B., Park, S.Y., Doh, K.O., 2014. Efficient delivery of plasmid DNA using cholesterol-based cationic lipids containing polyamines and ether linkages. Int. J. Mol. Sci. 15, 7293-7312. https://doi.org/10.3390/ijms15057293

32. Kim, H.K., Davaa, E., Myung, C.S., Park, J.S., 2010. Enhanced siRNA delivery using cationic liposomes with new polyarginine-conjugated PEG-lipid. Int. J. Pharm. 392, 141-147. https://doi.org/10.1016/j.ijpharm.2010.03.047

33. Lee, Y., Messing, A., Su, M., Brenner, M., 2008. GFAP promoter elements required for region-specific and astrocyte-specific expression. Glia. https://doi.org/10.1002/glia.20622

34. Leßmann, V., Brigadski, T., 2009. Mechanisms, locations, and kinetics of synaptic BDNF secretion: An update. Neurosci. Res. 65, 11-22. https://doi.org/10.1016/J.NEURES.2009.06.004

35. Lessmann, V., Gottmann, K., Malcangio, M., 2003. Neurotrophin secretion: current facts and future prospects. Prog. Neurobiol. 69, $341-374$. https://doi.org/10.1016/S0301-0082(03)00019-4

36. Li, X.M., Ding, L.Y., Xu, Y., Wang, Y., Ping, Q.N., 2009. Targeted delivery of doxorubicin using stealth liposomes modified with transferrin. Int. J. Pharm. 373, 116-123. https://doi.org/10.1016/j.ijpharm.2009.01.023

37. Macherey-Nagel, 2011. Plasmid DNA Purification User Manual NucleoBond ${ }^{\circledR}$ Xtra Midi. Cell.

38. Manjappa, A.S., Chaudhari, K.R., Venkataraju, M.P., Dantuluri, P., Nanda, B., Sidda, C., Sawant, K.K, Ramachandra Murthy, R.S., 2011. Antibody derivatization and conjugation strategies: Application in preparation of stealth immunoliposome to target chemotherapeutics to tumor. J. Control. Release. https://doi.org/10.1016/j.jconrel.2010.11.002

39. Molteni, R., Cattaneo, A., Calabrese, F., Macchi, F., Olivier, J.D.A., Racagni, G., Ellenbroek, B.A., Gennarelli, M., Riva, M.A., 2010. Reduced function of the serotonin transporter is associated with decreased expression of BDNF in rodents as well as in humans. Neurobiol. Dis. 37, 747-755. https://doi.org/10.1016/j.nbd.2009.12.014

40. Morris, V.B., Labhasetwar, V., 2015. Arginine-rich polyplexes for gene delivery to neuronal cells. Biomaterials. https://doi.org/10.1016/j.biomaterials.2015.04.052

41. Nobs, L., Buchegger, F., Gurny, R., Allémann, E., 2004. Current methods for attaching targeting ligands to liposomes and nanoparticles. J. Pharm. Sci. https://doi.org/10.1002/jps.20098

42. Obata, Y., Ciofani, G., Raffa, V., Cuschieri, A., Menciassi, A., Dario, P., Takeoka, S., 2010. Evaluation of cationic liposomes composed of an amino acidbased lipid for neuronal transfection. Nanomedicine Nanotechnology, Biol. Med. https://doi.org/10.1016/j.nano.2009.04.005

43. Pardridge, W.M., 2020. Blood-Brain Barrier and Delivery of Protein and Gene Therapeutics to Brain. Front. Aging Neurosci. 11, 1-27. https://doi.org/10.3389/fnagi.2019.00373

44. Pardridge, W.M., 2015. Targeted delivery of protein and gene medicines through the blood-brain barrier. Clin. Pharmacol. Ther. https://doi.org/10.1002/cpt.18

45. Pardridge, W.M., 2012. Drug transport across the blood-brain barrier. J. Cereb. Blood Flow Metab. 32, $1959-72$. https://doi.org/10.1038/jcbfm.2012.126

46. Parker, A.L., Newman, C., Briggs, S., Seymour, L., Sheridan, P.J., 2003. Nonviral gene delivery: techniques and implications for molecular medicine. Expert Rev. Mol. Med. 5, 1-15. https://doi.org/10.1017/S1462399403006562

47. Pecora, R., 2000. Dynamic light scattering measurement of nanometer particles in liquids. J. Nanoparticle Res. https://doi.org/10.1023/A:1010067107182

48. Podesta, J.E., Kostarelos, K., 2009. Engineering Cationic Liposome, in: Methods in Enzymology. pp. 343-354. https://doi.org/10.1016/S00766879(09)64017-9

49. Polyakova, M., Stuke, K., Schuemberg, K., Mueller, K., Schoenknecht, P., Schroeter, M.L., 2015. BDNF as a biomarker for successful treatment of mood disorders: A systematic \& quantitative meta-analysis. J. Affect. Disord. https://doi.org/10.1016/j.jad.2014.11.044

50. Poo, M., 2001. NEUROTROPHINS AS SYNAPTIC MODULATORS 2, 24-32.

51. Pruunsild, P., Kazantseval, A., Aid, T., Palm, K., Timmusk, T., 2007. Dissecting the human BDNF locus: Bidirectional transcription, complex splicing, and multiple promoters. Genomics. https://doi.org/10.1016/j.ygeno.2007.05.004

52. Quesseveur, G., David, D.J., Gaillard, M.C., Pla, P., Wu, M. V., Nguyen, H.T., Nicolas, V., Auregan, G., David, I., Dranovsky, A., Hantraye, P., Hen, R., Gardier, A.M., Déglon, N., Guiard, B.P., 2013. BDNF overexpression in mouse hippocampal astrocytes promotes local neurogenesis and elicits anxiolytic-like activities. Transl. Psychiatry 3. https://doi.org/10.1038/tp.2013.30

53. Radaev, S., Sun, P.D., 2002. Crystallization of protein-protein complexes. J. Appl. Crystallogr. https://doi.org/10.1107/S0021889802013973

54. Rasmussen, M., Kong, L., Zhang, G. rong, Liu, M., Wang, X., Szabo, G., Curthoys, N.P., Geller, A.I., 2007. Glutamatergic or GABAergic neuron-specific, 
bioRxiv preprint doi: https://doi.org/10.1101/2020.06.25.171264; this version posted June 26, 2020. The copyright holder for this preprint (which was not certified by peer review) is the author/funder. All rights reserved. No reuse allowed without permission.

\section{M. Diniz et al.}

long-term expression in neocortical neurons from helper virus-free HSV-1 vectors containing the phosphate-activated glutaminase, vesicular glutamate transporter-1, or glutamic acid decarboxylase promoter. Brain Res. https://doi.org/10.1016/j.brainres.2007.01.125

55. Ray, M.T., Weickert, C.S., Wyatt, E., Webster, M.J., 2011. Decreased BDNF, trkB-TK+ and GAD67 mRNA expression in the hippocampus of individuals with schizophrenia and mood disorders. J. Psychiatry Neurosci. https://doi.org/10.1503/jpn.100048

56. Rip, J., Chen, L., Hartman, R., Van Den Heuvel, A., Reijerkerk, A., Van Kregten, J., Van Der Boom, B., Appeldoorn, C., De Boer, M., Maussang, D., De Lange, E.C.M., Gaillard, P.J., 2014. Glutathione PEGylated liposomes: Pharmacokinetics and delivery of cargo across the blood-brain barrier in rats. J. Drug Target. 22, 460-467. https://doi.org/10.3109/1061186X.2014.888070

57. Ross, C., Taylor, M., Fullwood, N., Allsop, D., 2018. Liposome delivery systems for the treatment of Alzheimer's disease. Int. J. Nanomedicine. https://doi.org/10.2147/IJN.S183117

58. Sakurai, F., Inoue, R., Nishino, Y., Okuda, A., Matsumoto, O., Taga, T., Yamashita, F., Takakura, Y., Hashida, M., 2000. Effect of DNA/liposome mixing ratio on the physicochemical characteristics, cellular uptake and intracellular trafficking of plasmid DNA/cationic liposome complexes and subsequent gene expression. J. Control. Release. https://doi.org/10.1016/S0168-3659(99)00280-1

59. Saraiva, C., Praça, C., Ferreira, R., Santos, T., Ferreira, L., Bernardino, L., 2016. Nanoparticle-mediated brain drug delivery: Overcoming blood-brain barrier to treat neurodegenerative diseases. J. Control. Release 235, 34-47. https://doi.org/10.1016/j.jconrel.2016.05.044

60. Scientific, T., 2007. BCA TM Protein Assay Kit. BCA Protein Assay Kit. https://doi.org/10.1016/j.ijproman.2010.02.012

61. Sen, S., Duman, R., Sanacora, G., 2008. Serum Brain-Derived Neurotrophic Factor, Depression, and Antidepressant Medications: Meta-Analyses and Implications. Biol. Psychiatry 64, 527-532. https://doi.org/10.1016/J.BIOPSYCH.2008.05.005

62. Serlin, Y., Shelef, I., Knyazer, B., Friedman, A., 2015. Anatomy and physiology of the blood-brain barrier. Semin. Cell Dev. Biol. https://doi.org/10.1016/j.semcdb.2015.01.002

63. Sharma, G., Modgil, A., Layek, B., Arora, K., Sun, C., Law, B., Singh, J., 2013. Cell penetrating peptide tethered bi-ligand liposomes for delivery to brain in vivo: Biodistribution and transfection. J. Control. Release 167, 1-10. https://doi.org/10.1016/j.jconrel.2013.01.016

64. Sharma, G., Modgil, A., Sun, C., Singh, J., 2012. Grafting of cell-penetrating peptide to receptor-targeted liposomes improves their transfection efficiency and transport across blood-brain barrier model. J. Pharm. Sci. https://doi.org/10.1002/jps.23152

65. Sonali, Singh, R.P., Singh, N., Sharma, G., Vijayakumar, M.R., Koch, B., Singh, S., Singh, U., Dash, D., Pandey, B.L., Muthu, M.S., 2016. Transferrin liposomes of docetaxel for brain-targeted cancer applications: formulation and brain theranostics. Drug Deliv. https://doi.org/10.3109/10717544.2016.1162878

66. Sonavane, G., Tomoda, K., Makino, K., 2008. Biodistribution of colloidal gold nanoparticles after intravenous administration: Effect of particle size. Colloids Surfaces B Biointerfaces. https://doi.org/10.1016/j.colsurfb.2008.07.004

67. Tattini, V., Parra, D.F., Polakiewicz, B., Pitombo, R.N.M., 2005. Effect of lyophilization on the structure and phase changes of PEGylated-bovine serum albumin. Int. J. Pharm. 304, 124-134. https://doi.org/10.1016/j.jijpharm.2005.08.006

68. Urtti, A., Polansky, J., Lui, G.M., Szoka, F.C., 2000. Gene delivery and expression in human retinal pigment epithelial cells: Effects of synthetic carriers, serum, extracellular matrix and viral promoters. J. Drug Target. https://doi.org/10.3109/10611860009102216

69. Visser, C.C., Stevanović, S., Voorwinden, L.H., Van Bloois, L., Gaillard, P.J., Danhof, M., Crommelin, D.J.A., De Boer, A.G., 2005. Targeting liposomes with protein drugs to the blood-brain barrier in vitro. Eur. J. Pharm. Sci. 25, 299-305. https://doi.org/10.1016/j.ejps.2005.03.008

70. Zhang, Y., Wang, J., Bian, D., Zhang, X., Zhang, Q., 2010. Targeted delivery of RGD-modified liposomes encapsulating both combretastatin A-4 and doxorubicin for tumor therapy: In vitro and in vivo studies. Eur. J. Pharm. Biopharm. 74, 467-473. https://doi.org/10.1016/j.ejpb.2010.01.002 